\title{
The possibilities of improvement of spark ignition engine efficiency through dual fueling of methanol and gasoline
}

\begin{abstract}
The paper presents the results of the investigations into a dual fuel spark ignition multipoint methanol/gasoline injection engine where the injection is realized into the area of the intake valve. The engine fuel feed was realized through a prototype intake system having double electronically controlled injectors. The here used system can feed the engine with gasoline and methanol separately and the combustion of the mixture of the said fuels with any given methanol content. The test were performed on a 4-cylinder spark ignition engine (Fiat 1100 MPI). The paper presents the comparative results of the efficiency of the dual fuelled engine at variable methanol content. The investigations revealed an advantageous influence of methanol addition on the engine efficiency, particularly for higher methanol content and higher loads.
\end{abstract}

Key words: dual fuel engine, methanol, overall efficiency, exhaust emissions

\section{Możliwości poprawy sprawności silnika o zapłonie iskrowym przez dwupaliwowe zasilanie alkoholem metylowym i benzyną}

\begin{abstract}
W artykule przedstawiono wyniki badań dwupaliwowego silnika o zapłonie iskrowym z wielopunktowym wtryskiem alkoholu i benzyny w okolice zaworu dolotowego. Zasilanie silnika realizowano przez prototypowy układ dolotowy zawierajacy podwójne wtryskiwacze sterowane elektronicznie. Zastosowany system umożliwia zasilanie silnika sama benzyna lub alkoholem oraz spalanie równoczesne mieszaniny obydwu paliw o dowolnym udziale alkoholu. Badania wykonano na 4-cylindrowym silniku o zapłonie iskrowym Fiat 1100 MPI. W artykule przedstawiono porównawcze wyniki badań sprawności silnika zasilanego dwupaliwowo o zmiennym udziale alkoholu metylowego. Badania pokazały korzystny wpływ dodatku alkoholu na sprawność silnika, szczególnie dla większych udziałów alkoholu i obciążeń silnika.
\end{abstract}

Słowa kluczowe: silnik dwupaliwowy, alkohol metylowy, sprawność ogólna, toksyczność spalin

\section{Introduction}

A growing interest in alcohol application in engine fuelling has been observed for many decades now [1-6]. A particularly high trend in this matter was observed in the 1970s of the last century and was triggered by the fuel crisis and a sharp growth of the crude oil prices. The fact that the content of lead compounds (additives boosting the fuel octane number) was limited in the fuel also contributed to the situation. The engineers began to use mixtures of gasoline and alcohol, chiefly due to the need of boosting the fuel octane number. The basic problem of this type of fueling was the phenomenon of splitting of these mixtures at lower temperatures and in the presence of water. For this reason the alcohol content in the mixtures was limited to a few per cent. This content could be increased through the use of stabilizers such as ethers, yet even that additive could not increase the alcohol content more than several per cent by volume. A more advantageous is the exclusive use of methanol for it takes advantage of the high knocking resistance allowing an increase in the compression ratio and engine overall efficiency including its unit power output [2, $3,7,11]$. This trend is particularly well developed in Brazil where approximately 2 million ethanol fueled vehicles (made from cassava and sugar cane) are used [12].

A common application of multipoint injection for light fuels opens up new possibilities of adding alcohol to gasoline.

\section{Wstęp}

Zainteresowanie zastosowaniem alkoholi do zasilania silników obserwowane jest od kilkudziesięciu lat [1-6]. Szczególne nasilenie tych tendencji wystąpiło w latach siedemdziesiątych ubiegłego wieku i było spowodowane poważnym kryzysem paliwowym oraz gwałtownym wzrostem cen ropy naftowej. Nie bez znaczenia było również ograniczenie stosowania związków ołowiu jako dodatków zwiększających liczbę oktanową benzyn. Zaczęto wtedy stosować mieszaniny benzyny i alkoholu, głównie ze względu na potrzebę zwiększenia jej liczby oktanowej. Podstawowym problemem tego zasilania było jednak zjawisko rozwarstwiania mieszanin w niskich temperaturach i w obecności wody. $\mathrm{Z}$ tego powodu zawartość alkoholu w mieszaninach była ograniczona do kilku procent. Zawartość tę można było zwiększyć przez zastosowanie stabilizatorów takich jak etery, jednak i tak dodatek alkoholu nie przekraczał kilkunastu procent objętościowych. Znacznie korzystniejsze jest stosowanie alkoholu jako paliwa samoistnego, bowiem pozwala ono w pełni wykorzystać dużą odporność przeciwstukową alkoholu umożliwiającą zwiększenie stopnia sprężania i wzrost sprawności ogólnej oraz mocy jednostkowej silnika $[2,3,7,11]$. Kierunek ten jest szczególnie rozwinięty w Brazylii, gdzie jest eksploatowanych około 2 mln samochodów zasilanych alkoholem etylowym pozyskiwanym $\mathrm{z}$ manioku i trzciny cukrowej [12]. 
In the solution described in this paper additional injectors for each cylinder were applied. The original injectors were used for the injection of methanol and the additional ones for the injection of gasoline. This system enables a simultaneous feed of methanol and gasoline and the content of methanol may vary in the range $0 \div 100 \%$ depending on the engine load and engine speed [7-9]. The assumption behind the investigations was feeding of the engine exclusively with gasoline or gasoline and a small amount of methanol at small loads. The content of methanol grew as the engine load increased. The composition of the mixture was controlled by the opening time of the gasoline and methanol injectors. The planned final stage of the research will be the increase in the compression ratio up to the values limiting the knocking combustion when fueled exclusively with methanol. This will allow an increase in the engine efficiency at part loads when the engine is fueled mainly with gasoline. It should be noted that this trend in the fueling is currently investigated by Volvo and Ford, which is confirmed in the literature [13].

\section{Engine fuel feed}

The idea behind the prototype engine fuel feed is the application of two injectors in each cylinder (separate for gasoline and methanol). The schematics of the prototype intake manifold have been presented in Fig. 1. The additional injectors were placed in the front part of the manifold. This required a modification of the manifold in order to enable the fitting of the injectors and making a new fuel rail for the additional injectors. For the fitting of the injectors steel sleeves were used glued into the manifold with an epoxy. The need to make the fuel rail resulted from a different than original distance between the injectors $(37 \mathrm{~mm})$. Methanol was injected through a standard gasoline injector and gasoline was injected through an additional injector. A more detailed description of the engine and the test stand has been shown in works $[7,8]$.

The tests were carried out on a 4-cylinder spark ignition multipoint injection engine (Fiat $1100 \mathrm{MPI}$ ). The technical data of this engine were shown in Table 1.

\section{Test results analysis}

The comparative tests of the dual fueling were carried out with 20,40, 60, 80 and 100\% methanol. The injection

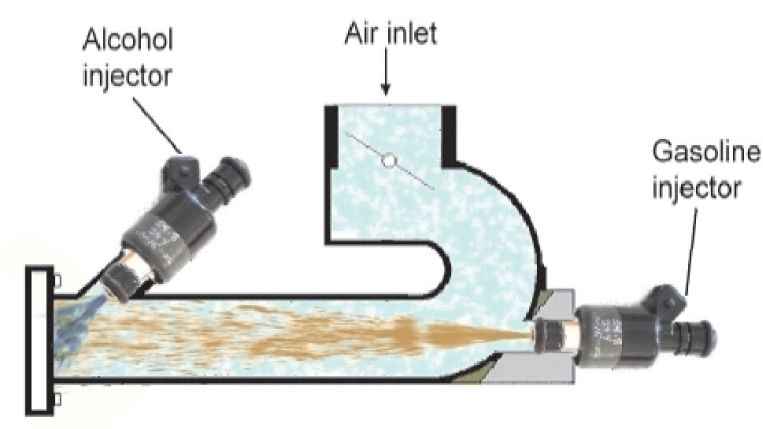

Fig. 1. Schematics of the prototype intake manifold of Fiat 1100 MPI Rys. 1. Schemat prototypowego kolektora dolotowego silnika Fiat 1100 MPI
Powszechne stosowanie wielopunktowego wtrysku paliw lekkich stwarza nowe możliwości w zakresie wielkości dodatku alkoholi do benzyn. W rozwiązaniu opisywanym w niniejszej pracy zastosowano dodatkowe wtryskiwacze na każdym cylindrze, przy czym oryginalne wtryskiwacze przeznaczono do wtrysku alkoholu, natomiast dodatkowe do wtrysku benzyny. System ten umożliwia równoczesne zasilanie silnika benzyną i alkoholem, a udział alkoholu może zmieniać się w granicach $0 \div 100 \%$ zależnie od obciążenia i prędkości obrotowej silnika [7-9]. Założeniem przeprowadzonych prac badawczych było zasilanie silnika przy małych obciążeniach samą benzyną lub mieszaniną z niewielkim dodatkiem alkoholu. Udział alkoholu zwiększał się w miarę wzrostu obciążenia silnika. Właściwy skład spalanej mieszaniny palnej sterowany był czasem otwarcia wtryskiwaczy benzynowego i alkoholowego. Końcowym etapem prac będzie zwiększenie stopnia sprężania do wartości ograniczonych spalaniem stukowym przy zasilaniu samym alkoholem. Pozwoli to na zwiększenie sprawności silnika przy częściowych obciążeniach, kiedy silnik będzie zasilany w głównej mierze benzyną. Należy zaznaczyć, że ten kierunek zasilania jest obecnie badany przez firmy Volvo i Ford, o czym świadczą doniesienia literaturowe [13].

\section{System zasilania silnika}

Istotą prototypowego systemu zasilania jest zastosowanie podwójnych wtryskiwaczy na każdym cylindrze, do wtrysku alkoholu i benzyny. Schemat prototypowego kolektora dolotowego przedstawiono na rys. 1. Dodatkowe wtryskiwacze umieszczono w przedniej części kolektora. Wymagało to przeróbki kolektora umożliwiającej montaż wtryskiwaczy oraz wykonania nowej szyny paliwowej dla wtryskiwaczy dodatkowych. Do montażu wtryskiwaczy zastosowano tulejki stalowe wklejone do kolektora na kleju epoksydowym. Konieczność wykonania prototypowej szyny paliwowej wynikała $\mathrm{z}$ innego rozstawu wtryskiwaczy wynoszącego $37 \mathrm{~mm}$. Alkohol wtryskiwany był przez wtryskiwacz benzyny stosowany w standardowym silniku, benzyna przez wtryskiwacz dodatkowy. Dokładniejsze opisy silnika i stanowiska badawczego przedstawiono $\mathrm{w}$ pracach $[7,8]$.

Badania przeprowadzono na 4-cylindrowym silniku o zapłonie iskrowym z wielopunktowym wtryskiem paliwa typ Fiat 1100 MPI. Dane techniczne silnika zamieszczono w tabeli 1.

Table 1. Technical data of the Fiat engine (1100 MPI) Tabela 1. Dane techniczne silnika Fiat 1100 MPI

\begin{tabular}{|l|c|}
\hline Engine type/typ silnika & Fiat $1100 \mathrm{MPI}$ \\
\hline Bore x stroke/średnica cylindra x skok & $70 \times 72 \mathrm{~mm}$ \\
\hline Displacement/pojemność skokowa & $1108 \mathrm{~cm}^{3}$ \\
\hline Compression ratio/stopień sprężania & 9.6 \\
\hline $\begin{array}{l}\text { Power output/engine speed/moc znamiono- } \\
\text { wa/prędkość obrotowa }\end{array}$ & $40 \mathrm{~kW} / 5000 \mathrm{rpm}$ \\
\hline $\begin{array}{l}\text { Maximum torque/engine speed/maksymalny } \\
\text { moment obrotowy/prędkość obrotowa }\end{array}$ & $88 \mathrm{~N} \cdot \mathrm{m} / 3000 \mathrm{rpm}$ \\
\hline
\end{tabular}


timing was identical as in the case of gasoline fueling. The comparison of the engine parameters consisted in a referral to the values obtained when fueled with gasoline only injected through the original injector of the standard engine. In the dual fueling gasoline was injected through the additional injector and methanol through the original injector. We should note that at low alcohol content, a large content of gasoline injected through the additional injector located far from the intake valve deteriorates the conditions of gasoline-air mixture formation, which could have an effect on the engine parameters.

The comparison of the overall efficiency of the engine in the function of engine load for different methanol content has been shown in Fig. 2. The energy methanol share has been determined from the dependence:

$$
\mathrm{U}_{\mathrm{m}}=\frac{\mathrm{G}_{\mathrm{m}} \cdot \mathrm{H}_{\mathrm{m}}}{\mathrm{G}_{\mathrm{b}} \cdot \mathrm{H}_{\mathrm{b}}+\mathrm{G}_{\mathrm{m}} \cdot \mathrm{H}_{\mathrm{m}}} \cdot 100 \%
$$

where: $\mathrm{G}_{\mathrm{m}}, \mathrm{G}_{\mathrm{b}}$ - hourly methanol and gasoline consumption $[\mathrm{kg} / \mathrm{h}], \mathrm{H}_{\mathrm{m}}, \mathrm{H}_{\mathrm{b}}-$ calorific value of methanol and gasoline $[\mathrm{J} / \mathrm{kg}]$.

The addition of methanol results in an increase of the overall engine as the methanol, content and engine load grow. For higher methanol content the efficiency was higher than when fueled with gasoline only. Particularly high differences occur when fuelling with pure methanol ( $100 \%$ content). For a small addition of methanol ( $20 \%$ content) at low engine loads, the efficiency under dual fueling was lower than under traditional fueling. This however does not challenge the positive impact of the methanol addition on the engine efficiency as the results were probably affected by the fact that under dual fueling gasoline was injected through an additional injector distant from the intake valve. This influenced the conditions of gasoline-air mixture formation decided about the obtained efficiency (the gasoline content in the mixture was higher and the engine load low). Under the discussed engine operating conditions the advantageous influence of methanol, proportional to its content in the charge, did not compensate the loss of efficiency caused by the deterioration of the conditions of evaporation and mixing of the gasolineair mixture. We should note that earlier, preliminary tests, performed after fitting of the prototype manifold have shown an adverse effect of the injection location on the engine efficiency. The authors think that better results would have been obtained if a preliminary methanol and gasoline mixer had been installed and an injection of the prepared mixture been realized through the original injector. These issues are to be investigated in detail in further research.

It is worth noting that when fueling exclusively with methanol the engine developed a torque of approximately $5 \%$ more as opposed to gasoline fueling. This has been obtained without changing of the ignition timing; hence, we can assume that the engine performance can still be better if the engine is fueled with methanol and properly optimized. The analysis presented in this paper was limited to the points of work for the same engine loads. With this as-

\section{Analiza wyników badań}

Badania porównawcze zasilania dwupaliwowego wykonano przy udziale alkoholu metylowego 20, 40, 60, 80 i $100 \%$ liczonym energetycznie. Kąt wyprzedzenia wtrysku był identyczny jak przy zasilaniu benzyną. Porównanie wartości parametrów silnika odnoszono do wartości uzyskanych przy zasilaniu samą benzyną, wtryskiwaną przez oryginalny wtryskiwacz standardowego silnika. Przy zasilaniu dwupaliwowym benzyna była wtryskiwana przez wtryskiwacz dodatkowy a alkohol przez wtryskiwacz fabryczny. Należy zaznaczyć, że przy małych udziałach alkoholu, duża ilość benzyny wtryskiwana przez dodatkowy wtryskiwacz oddalony od zaworu dolotowego pogarsza warunki tworzenia mieszaniny benzyna-powietrze, co mogło mieć wpływ na parametry silnika.

Porównanie sprawności ogólnej silnika w funkcji obciążenia silnika dla różnych udziałów metanolu przedstawiono na rys. 2. Energetyczny udział metanolu określano z zależności (1),

gdzie: $\mathrm{G}_{\mathrm{m}}, \mathrm{G}_{\mathrm{b}}$ - godzinowe zużycia metanolu i benzyny $[\mathrm{kg} / \mathrm{h}], \mathrm{H}_{\mathrm{m}}, \mathrm{H}_{\mathrm{b}}-$ wartość opałowa metanolu i benzyny $[\mathrm{J} / \mathrm{kg}]$.

Dodatek metanolu powoduje zwiększenie sprawności ogólnej silnika w miarę powiększania udziału metanolu i obciążenia silnika. Dla większych udziałów metanolu sprawności były większe od występujących przy zasilaniu samą benzyną. Szczególnie duże różnice występują przy zasilaniu samym metanolem (udział 100\%). Dla niewielkiego dodatku metanolu (udział 20\%) przy małych obciążeniach, sprawność przy zasilaniu dwupaliwowym była mniejsza niż przy zasilaniu tradycyjnym. Nie podważa to jednak korzystnego wpływu dodatku metanolu na sprawność, bowiem wpływ na wyniki miał prawdopodobnie fakt, że przy zasilaniu dwupaliwowym benzyna była wtryskiwana przez dodatkowy wtryskiwacz oddalony od zaworu dolotowego. Miało to wpływ na warunki tworzenia mieszaniny benzyna-powietrze i przy przewadze udziału benzyny oraz małych obciążeniach silnika decydowało o uzyskiwanej sprawności. W omawianych warunkach pracy silnika korzystny wpływ metanolu, proporcjonalny do jego udziału w ładunku, nie kompensował straty sprawności powodowanej pogorszeniem warunków odparowania i mieszania benzyny z powietrzem. Należy zaznaczyć, że już wcześniejsze badania wstępne wykonane po zamontowaniu prototypowego kolektora wykazały niekorzystny wpływ zmiany położenia punktu wtrysku benzyny na sprawność silnika. Wydaje się, że korzystniejsze wyniki można byłoby uzyskać przy zastosowaniu mieszalnika wstępnego alkoholu i benzyny, i wtrysku przygotowanej wcześniej mieszaniny przez oryginalny wtryskiwacz. Zagadnieniom tym będą poświęcone planowane w przyszłości badania.

Warto podkreślić, że przy zasilaniu samym metanolem silnik rozwijał moment obrotowy większy o około $5 \% \mathrm{w}$ stosunku do zasilania benzyną. Wynik ten uzyskano bez optymalizacji kąta wyprzedzenia zapłonu, a więc można zakładać, że osiągi silnika przy zasilaniu metanolem i optymalizacji regulacji mogą być jeszcze wyższe. W analizie 
a)

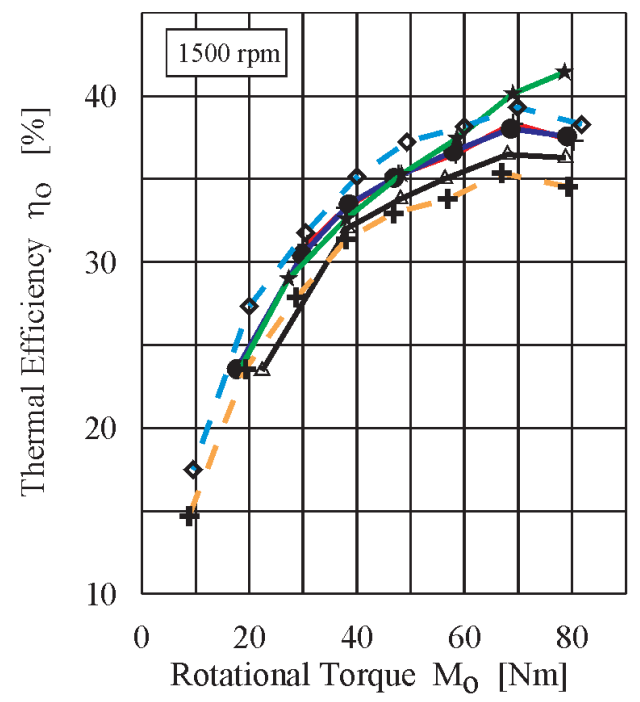

c)

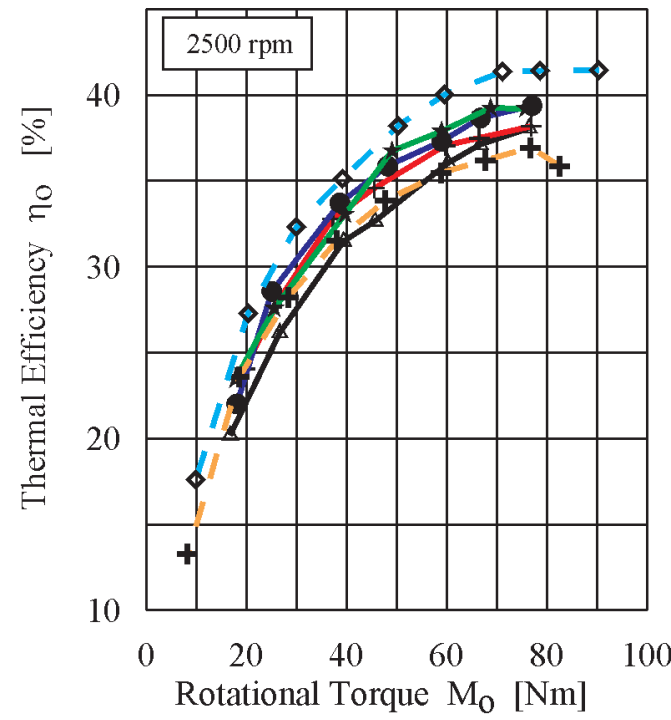

b)

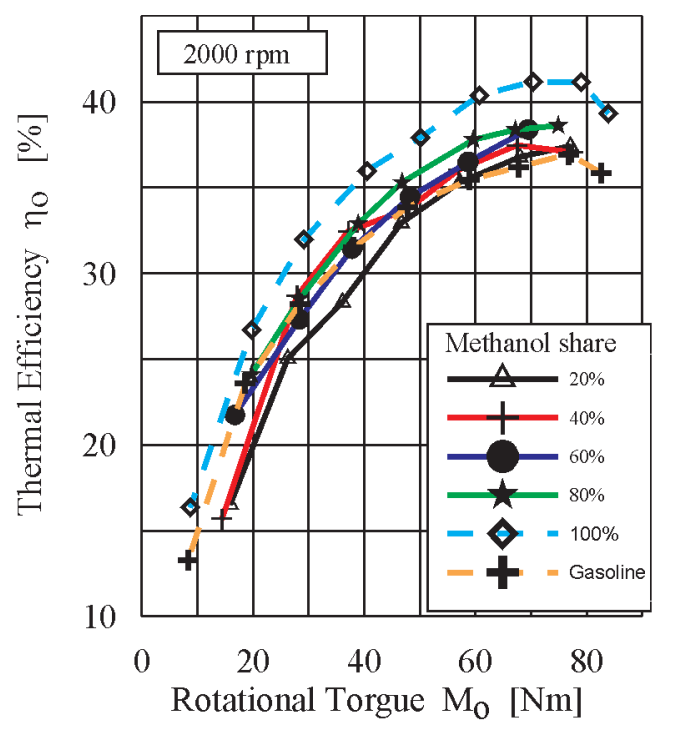

d)

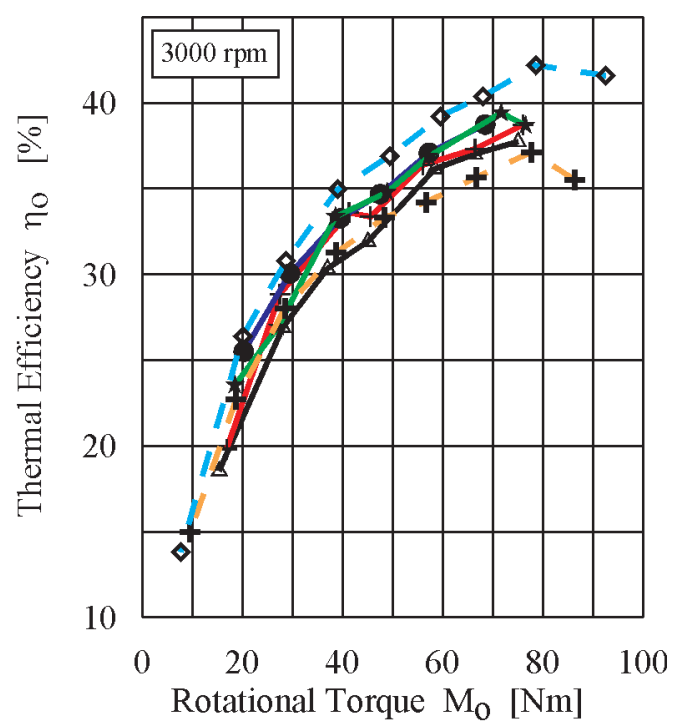

Fig. 2. The comparison of thermal efficiency of the engine fueled with gasoline only and dual fuel for different methanol content

Rys. 2. Porównanie sprawności ogólnej silnika zasilanego samą benzyną i dwupaliwowo przy różnych udziałach metanolu

sumption the engine points of work of higher torque as opposed to gasoline fueling have been omitted.

The comparison of the engine overall efficiency, shown in Fig. 2 indicates that the dual fueled engine operates with a higher efficiency almost in the whole range of engine load and engine speed. The differences in the efficiencies grow as the methanol content in the charge and the load increase. In the range of medium and maximum loads the absolute differences are $2-5 \%$, which gives an absolute increase in the efficiency of 6-16\%, decisive of the operational energy consumption.

It seems that both the growth of the maximum operating parameters and engine efficiency could result from a higher speed of methanol combustion, which generates lower thermal losses in a cycle. At the same time, higher methanol heat of evaporation influences the reduction of the charge temperature in the compression stroke and in the beginning of the combustion, which could lead to a reduction of the mechanical losses in the compression stroke and, thus a boost przedstawionej w niniejszej pracy ograniczono się jedynie do punktów pracy dla tych samych obciążeń silnika. Przy tym założeniu punkty pracy silnika o większym momencie obrotowym w stosunku do zasilania benzyną zostały pominięte.

Porównanie sprawności ogólnej silnika przedstawione na rys. 2 wskazuje, że silnik zasilany dwupaliwowo pracuje z większą sprawnością prawie w całym zakresie zmian obciążenia i prędkości obrotowej. Równocześnie różnice w sprawnościach powiększają się wraz ze wzrostem udziału metanolu w ładunku i obciążenia silnika. W zakresie średnich i maksymalnych obciążeń różnice bezwzględne wynoszą 2-5\%, co daje wzrost względny sprawności, decydujący o eksploatacyjnych zużyciach energii, w zakresie 6-16\%.

Wydaje się, że zarówno wzrost maksymalnych parametrów eksploatacyjnych, jak i sprawności silnika może być spowodowany przez większą szybkość spalania metanolu, co powoduje mniejsze straty cieplne w cyklu. Równocześnie większe ciepło parowania metanolu wpływa na obniżenie 
in the efficiency. A further growth of the engine parameters could be obtained through increasing of the compression ratio and optimization of the engine settings. The proposed system of dual fueling with active methanol content adjustment depending on the engine load and engine speed enables the implementation of the discussed modifications.

The absolute change of the engine efficiency in the measuring points has been determined as the difference of efficiencies under dual fueling and traditional fueling at the same load and engine speed:

$$
\Delta \eta_{\mathrm{o}}=\eta_{\mathrm{d}}-\eta_{\mathrm{b}}
$$

where: $\Delta \eta_{\mathrm{o}}$ - change of the engine overall efficiency [\%], $\eta_{d}$ - engine efficiency under dual fueling $[\%], \eta_{b}$ - engine efficiency under gasoline fueling [\%].

The courses of absolute values of the efficiency changes under dual fueling have been presented in Fig. 3 and 4.

The influence of dual fueling on the operational fuel consumption can be determined through a relative change in the overall efficiency from the formula:

$$
\delta_{\mathrm{o}}=\frac{\Delta \eta_{\mathrm{o}}}{\eta_{\mathrm{b}}} \cdot 100 \%
$$

The courses of the values of the relative change in the overall engine efficiency in the function of engine load for different methanol content as shown in Fig. 5 indicate a significant improvement of the engine efficiency in medium and maximum engine loads, particularly for higher methanol content. The relative changes in the engine efficiency above $10 \%$ should contribute to the reduction of the operational fuel consumption and improvement of its environmental features. The analysis of fig. 5, however, indicates a drop in the efficiency in the range of lower engine loads. The relative changes in the efficiency under these conditions are important - they may have impact on the operational fuel consumption as the share of the engine operation at small loads is large, particularly in city traffic of high congestion.

The collection of all the layouts of values of the relative change of the efficiency on a plane $\delta_{\mathrm{o}}-\mathrm{M}_{\mathrm{o}}$ for the engine speed 1500 $4500 \mathrm{rpm}$ and methanol content $20-100 \%$ has been shown in Fig. 6 .

From the location of the points in Fig. 6 it results that in the majority of engine work states dual fueling increases the engine overall efficiency. A reduction in the efficiency at some measuring points, temperatury ładunku w czasie sprężania i na początku procesu spalania, co może prowadzić do zmniejszenia strat mechanicznych w suwie sprężania i powiększenia sprawności. Dalszy wzrost parametrów silnika może być osiągnięty przez zwiększenie stopnia sprężania i optymalizację regulacji silnika. Zaproponowany system dwupaliwowego zasilania z aktywną zmianą udziału alkoholu zależnie od obciążenia silnika i prędkości obrotowej umożliwia wprowadzenie sygnalizowanych zmian.

Bezwzględną zmianę sprawności silnika w punktach pomiarowych określono jako różnicę sprawności przy zasilaniu dwupaliwowym i tradycyjnym przy tym samym obciążeniu i prędkości obrotowej - wzór (2),

gdzie: $\Delta \eta_{\mathrm{o}}-$ zmiana sprawności ogólnej silnika $[\%], \eta_{\mathrm{d}}-$ sprawność silnika przy zasilaniu dwupaliwowym [\%], $\eta_{b}$ - sprawność silnika przy zasilaniu benzyną [\%].

Przebiegi wartości bezwzględnych zmian sprawności przy zasilaniu dwupaliwowym przedstawiono na rys. 3 i 4 .
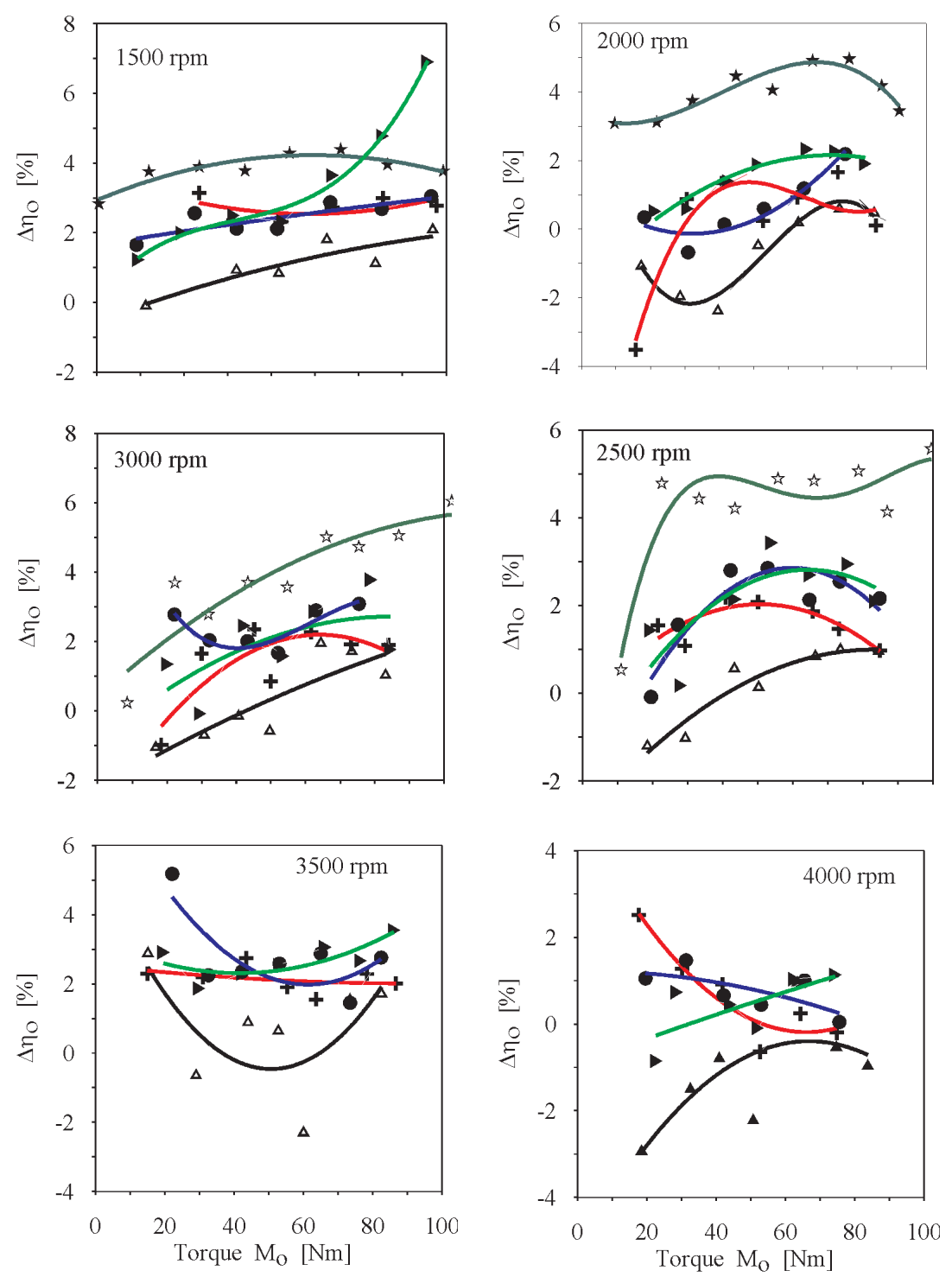

Fig. 3. Changes of thermal efficiency of dual fuelled engine for various methanol share Rys. 3. Zmiany sprawności silnika zasilanego dwupaliwowo przy różnych udziałach metanolu 

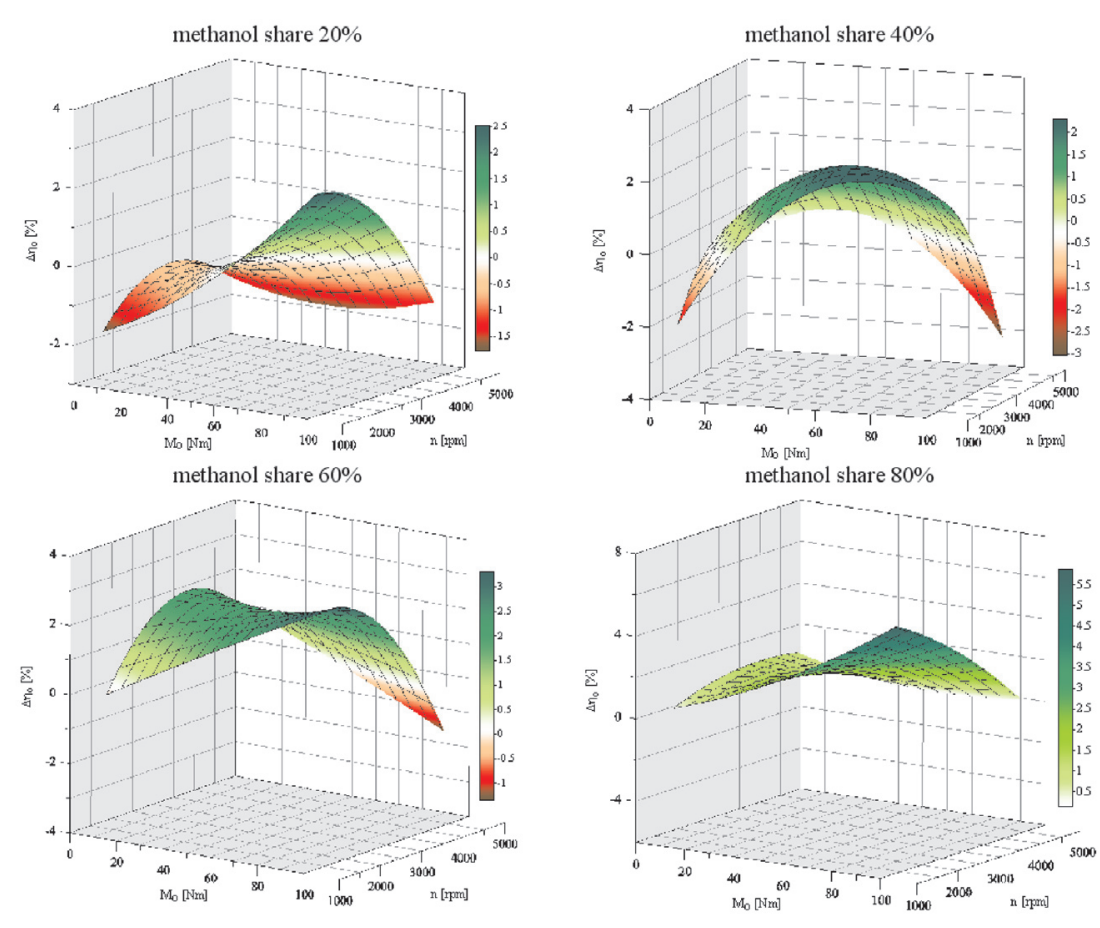

Fig. 4. Changes in thermal efficiency of dual fueled engine for constant methanol content

Rys. 4. Zmiany sprawności ogólnej silnika zasilanego dwupaliwowo dla stałych udziałów metanolu

particularly in the range of low loads and small methanol content could be attributed to the different gasoline injection as compared to the standard engine.

For a better depiction of the influence of dual fueling on the energy consumption an additional index was introduced (a product of an absolute change in the engine efficiency determined from formula (2) and power obtained by the engine at a given measuring point:

$$
\mathrm{Z}_{\mathrm{o}}=\Delta \eta_{\mathrm{o}} \cdot \mathrm{N}_{\mathrm{e}}
$$

where: $Z_{0}$ - energy advantage index resulting from dual fueling $[\% \mathrm{~kW}], \Delta \eta_{\mathrm{o}}-$ absolute change in the overall engine efficiency in the measuring point $[\%], \mathrm{N}_{\mathrm{e}}$ - engine power during the measuring while dual fueled [kW].

$\mathrm{Z}_{\mathrm{o}}$ can assume negative or positive values depending on the $\Delta \eta_{0}$. An additional parameter could be the sum of values $\mathrm{Z}_{\mathrm{o}}$ for $\mathrm{n}=$ const and $\mathrm{U}_{\mathrm{m}}=$ const while changing the engine load:

$$
\Omega=\sum_{\mathrm{i}=1}^{\mathrm{i}=\mathrm{n}}\left(\mathrm{Z}_{\mathrm{o}}\right)_{\mathrm{i}}
$$

where: $\Omega$ - the sum of indexes $Z_{o}$ of the load characteristics for $\mathrm{n}=$ const and $\mathrm{U}_{\mathrm{m}}=$ const $[\% \mathrm{~kW}],\left(\mathrm{Z}_{\mathrm{o}}\right)_{\mathrm{i}}-$ index value in an i-th measuring point.

According to the adopted definition the set of points of one load characteristic and one methanol content corresponds to one value of sum $\Omega$. The changes on the $\Omega$ value in the function of engine speed for constant methanol content have been shown in Fig. 7. The points located above the red
Wpływ dwupaliwowego zasilania silnika na eksploatacyjne zużycie paliwa może być określony przez względną zmianę sprawności ogólnej określonej z wzoru (3).

Przebiegi wartości względnej zmiany sprawności silnika w funkcji obciążenia dla różnych udziałów metanolu pokazane na rys. 5 wskazują na znaczącą poprawę sprawności silnika w zakresie średnich i maksymalnych obciążeń silnika, szczególnie dla większych udziałów metanolu. Zmiany względne sprawności powyżej $10 \%$ powinny przyczynić się do zmniejszenia eksploatacyjnego zużycia paliwa i poprawy jego cech ekologicznych. Analiza rys. 5 wskazuje jednak na zjawisko zmniejszenia sprawności w zakresie mniejszych obciążeń silnika. Względne zmiany sprawności w tych warunkach są istotne, co może wpływać na eksploatacyjne zużycie paliwa, bowiem udział pracy silnika na niewielkich obciążeniach jest znaczny, szczególnie w warunkach jazd miejskich o dużym natężeniu ruchu.

Zbiór rzutów wszystkich wartości względnej zmiany sprawności na płaszczyznę $\delta_{\mathrm{o}}-\mathrm{M}_{\mathrm{o}}$ dla prędkości obrotowych $1500-4500 \mathrm{obr} / \mathrm{min}$ i udziałów metanolu $20-100 \%$ przedstawiono na rys. 6 .

Z położenia punktów na rysunku 6 wynika, że w przeważającej liczbie stanów pracy silnika zasilanie dwupaliwowe korzystnie wpływa na sprawność ogólną powodując jej wzrost. Zmniejszenie sprawności w niektórych punktach pomiarowych, głównie w zakresie małych obciążeń i niewielkich udziałów metanolu, można wiązać z odmiennym wtryskiem benzyny w stosunku do wtrysku w silniku standardowym.

Dla lepszego zobrazowania wpływu zasilania dwupaliwowego na zużycie energii wprowadzono dodatkowy wskaźnik będący iloczynem bezwzględnej zmiany sprawności silnika określonej z wzoru (2) i mocy rozwijanej przez silnik w badanym punkcie pomiarowym - (4),

gdzie: $Z_{\mathrm{o}}$ - wskaźnik korzyści energetycznej wynikającej z zasilania dwupaliwowego [\%kW], $\Delta \eta_{\mathrm{o}}$ - bezwzględna zmiana sprawności ogólnej silnika w punkcie pomiarowym [\%], $\mathrm{N}_{\mathrm{e}}$ - moc silnika rozwijana w czasie pomiaru przy zasilaniu dwupaliwowym [kW]

Wartości wskaźnika $Z_{o}$ mogą przyjmować wartości ujemne lub dodatnie zależnie od znaku $\Delta \eta_{\mathrm{o}}$. Dodatkowym parametrem może być suma wartości $Z_{o}$ dla $n=$ const $\mathrm{i}_{\mathrm{m}}$ = const przy zmianach obciążenia silnika - (5),

gdzie: $\Omega$ - suma wskaźników $\mathrm{Z}_{\mathrm{o}}$ charakterystyki obciążeniowej dla $\mathrm{n}=$ const $\mathrm{i} \mathrm{U}_{\mathrm{m}}=$ const $[\% \mathrm{~kW}],\left(\mathrm{Z}_{\mathrm{o}}\right)_{\mathrm{i}}-$ wartość wskaźnika w i-tym punkcie pomiarowym.

Zgodnie z przyjętą definicją zbiorowi punktów jednej charakterystyki obciążeniowej i jednej wartości udziału 
zero line indicate an improvement of the collective efficiency within one load characteristic. The points located below the zero line indicate a deterioration of the efficiency and the operation of the engine on the analyzed load characteristic may lead to higher fuel consumption. The analysis of Fig. 7 shows that for the methanol content of more than $20 \%$ a reduction in energy consumption should take place during engine operation. The reduction of the $\Omega$ value for the speeds of 4000 and $4500 \mathrm{rpm}$ can be compensated with a change in the ignition timing.

$\mathrm{Z}_{\mathrm{o}}$ can also be summed up for constant engine speed and variable methanol content. $\Omega$ then, indicates the influence of methanol content

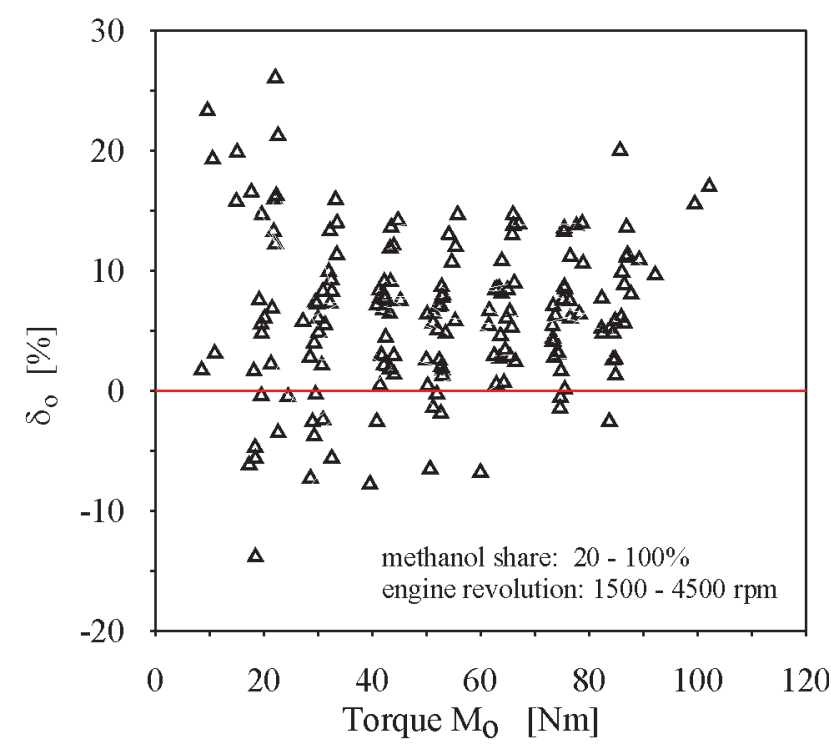

Fig. 6. Set of values the relativ changes of thermal efficiency in the examinations points for engine revolution 1500-4500 rpm and methanol share $20-100 \%$

Rys. 6. Zbiór wartości względnej zmiany sprawności ogólnej w badanych punktach pomiarowych dla przedziatu prędkości obrotowej 1500$4500 \mathrm{obr} / \mathrm{min}$ i udzialu metanolu 20-100\%
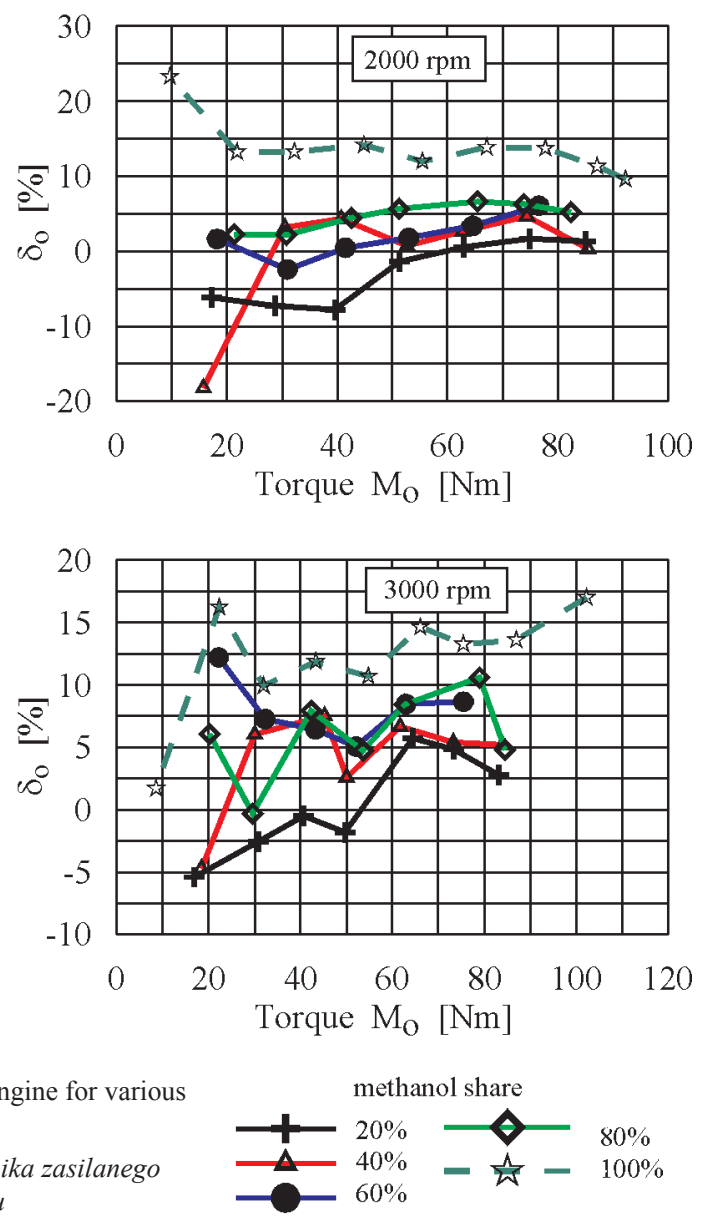

metanolu odpowiada jedna wartość sumy $\Omega$. Zmiany wartości $\Omega$ w funkcji prędkości obrotowej dla stałych udziałów metanolu przedstawiono na rys. 7. Punkty położone powyżej czerwonej linii zerowej wskazują na poprawę sprawności sumarycznej w ramach jednej charakterystyki obciążeniowej. Punkty położone poniżej linii zerowej świadczą o pogorszeniu sprawności i eksploatacja silnika na analizowanej charakterystyce obciążeniowej może prowadzić do zwiększenia zużycia paliwa. Analiza rys. 7 wskazuje, że dla udziałów metanolu powyżej 20\% powinno występować zmniejszenie zużycia energii w eksploatacji trakcyjnej silnika. Zmniejszenie wartości $\Omega$ dla prędkości 4000 i 4500 obr/min może być kompensowane zmianą kąta wyprzedzenia zapłonu.

Wartości $Z_{\circ}$ mogą być również sumowane dla stałej prędkości obrotowej i zmiennego udziału metanolu. Wartość $\Omega$ wskazuje wtedy na wpływ udziału metanolu na zużycie energii przy eksploatacji silnika przy stałej prędkości obrotowej. Zmiany wartości tak zdefiniowanych sum przedstawiono na rys. 8 . Z jego analizy wynika, że w przedziale zmienności prędkości obrotowej 1500-4000 obr/min występują wyraźne korzyści stosowania zasilania dwupaliwowego prowadzące do zwiększenia efektywności zużycia energii. Szczególnie duże wartości sumarycznego wskaźnika $\Omega$ występują w okolicach maksymalnego momentu obrotowego w przedziale prędkości obrotowej 2500-3500 obr/min. 
on the energy consumption at a steady engine speed. The changes in so defined sums have been presented in fig. 8 . From the analysis of the figure it results that in the range of engine speed of 1500-4000 rpm clearly there are advantages of applying dual fueling leading to an increase in the energetic efficiency. Particularly high values of collective index $\Omega$ occur around the maximum torque in the engine speed range of 2500-3500 rpm.

The total collective index $\Omega_{\text {sum }}$ calculated for all 256 tested measuring points in the engine speed range of 1500-4500 rpm and range of methanol content of $20-100 \%$ amounts to $\Omega_{\text {sum }}=$ $4996[\% \mathrm{~kW}]$. This indicates that even at certain imperfections in the mixture formation resulting from the application of the prototype intake manifold, dual fueling will cause significant economies in the energy use. A further improvement of the indexes we can expect after an optimization of the gasoline injector location, application of a single gasoline-methanol mixture injector and increasing of the engine compression ratio. It also seems that the obtained results may be translated onto other alcohols such as ethanol.

An additional effect of methanol application is an improvement of the engine ecological properties that result from the reduction of the $\mathrm{HC}$ and $\mathrm{NO}_{\mathrm{x}}$ concentration, which was indicated in previous works of the authors [7-9].

\section{Conclusions}

Based on the performed investigations we can draw the following general conclusions:

1.Dual fueling of an engine (gasoline and methanol) has an advantageous effect on the external parameters such as overall engine efficiency, maximum power output and maximum torque.

2. The overall engine efficiency grows as the methanol content and engine load increase. The absolute increase in the overall engine efficiency amounted to $2 \div 5 \%$ and the relative increase $-6 \div 16 \%$. A significant increase in

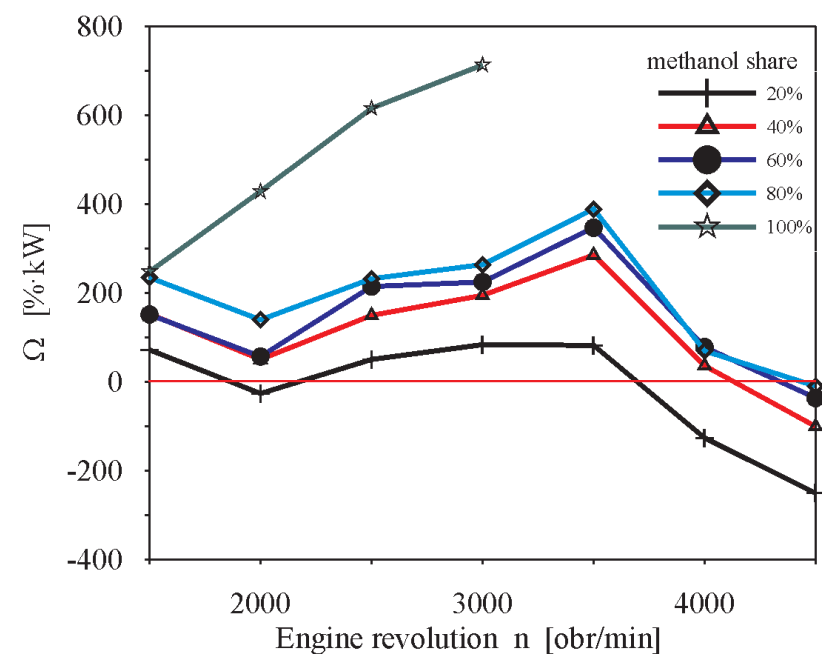

Fig. 7. Changes in the total index $\Omega$ in the function of engine revolutions for constant methanol content

Rys. 7. Zmiany sumarycznego wskaźnika $\Omega$ w funkcji prędkości obrotowej dla statych udziałów metanolu $w$ calkowitej dawce energii dostarczanej do silnika
Całkowity wskaźnik sumaryczny $\Omega_{\text {sum }}$ obliczony dla wszystkich 256 badanych punktów pomiarowych w zakresie zmian prędkości 1500-4500 obr/min i zmian udziału metanolu 20-100\% wynosi $\Omega_{\text {sum }}=4996[\% \mathrm{~kW}]$. Wskazuje to, że nawet przy pewnych niedoskonałościach w tworzeniu mieszaniny palnej wynikających z zastosowania prototypowego kolektora dolotowego, zasilanie dwupaliwowe będzie skutkować istotnymi oszczędnościami zużycia energii. Dalszej poprawy wskaźników można oczekiwać przy optymalizacji położenia wtryskiwacza benzyny, zastosowania pojedynczego wtryskiwacza mieszaniny metanol-benzyna oraz powiększeniu stopnia sprężania silnika. Wydaje się również, że uzyskane wyniki badań mogą być przenoszone na inne alkohole jak np. na alkohol etylowy.

Dodatkowym efektem zastosowania alkoholu jest poprawa własności ekologicznych silnika wynikająca ze zmniejszenia stężenia węglowodorów i tlenków azotu, co sygnalizowano we wcześniejszych publikacjach autorów [7-9].

\section{Wnioski}

Na podstawie przeprowadzonych badań można wyciągnąć następujące wnioski o charakterze ogólnym:

1. Dwupaliwowe zasilanie silnika benzyną i alkoholem korzystnie wpływa na parametry zewnętrzne silnika takie jak sprawność ogólna, moc maksymalna i maksymalny moment obrotowy.

2. Wzrost sprawności ogólnej silnika zwiększa się wraz ze zwiększaniem udziału metanolu i obciążenia silnika. Bezwzględny wzrost sprawności wynosił $2 \div 5 \%$, a wzrost względny w zakresie $6 \div 16 \%$. Znaczący wzrost sprawności silnika powinien prowadzić do zmniejszenia zużycia energii w eksploatacji i poprawy ekologicznych parametrów silnika.

3.Pogorszenie sprawności silnika w niektórych badanych punktach, szczególnie przy małych obciążeniach silnika i

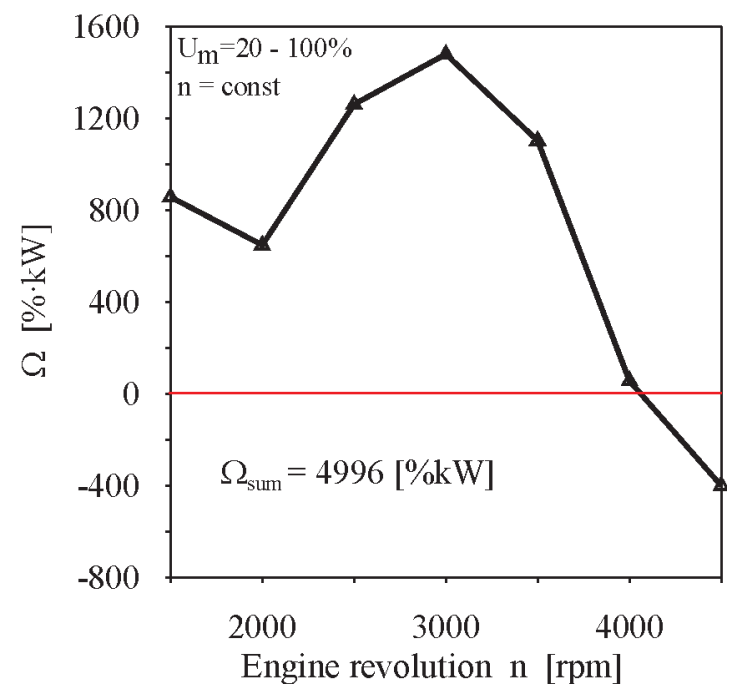

Fig. 8. Changes of the total index $\Omega$ calculate in the range methanol share $20-100 \%$ for constant engine speed

Rys. 8. Zmiany sumarycznego wskaźnika $\Omega$ obliczone w przedziale zmienności udziału metanolu 20-100\% dla statych prędkości obrotowych 
the engine efficiency should lead to a reduction in the operational energy consumption and an improvement of the ecological properties of the engine.

3. A deterioration of the engine efficiency at certain tested points (small loads and low methanol content in particular) can be attributed to the remoteness of the gasoline injector from the intake valve, which resulted from the application of an additional injector. This issue requires further investigations.

4. The analysis of the collective indexes of energy related advantages resulting from dual fueling indicates that the applied prototype fuel system should contribute to a significant reduction in the energy consumption by traction spark ignition engines.

5. The developed fueling system is characterized by a variety of advantages significant in dual fueling of spark ignition engines. These advantages are as follows:

- the possibility of engine startup using gasoline exclusively, which maintains its properties at startup as in traditional gasoline fueling;

- the possibility of dual fueling at actively variable methanol content depending on the engine load and speed;

- the possibility of using high methanol content without the risk of fuel splitting;

- the possibility of increasing the compression ratio and an automatic switch to methanol fueling at maximum engine loads.

The here presented investigations were carried out within the research grant no. PB 45343/B/T02/2007/33 financed by The Ministry of Science and Higher Education. małych udziałach metanolu, można wiązać z oddaleniem punktu wtrysku benzyny od zaworu dolotowego wynikającym z zastosowania dodatkowego wtryskiwacza. Zagadnienie to wymaga dalszych badań.

4. Analiza sumarycznych wskaźników korzyści energetycznych wynikających z zastosowania zasilania dwupaliwowego wskazuje, że zastosowany prototypowy układ zasilania powinien przyczynić się do znaczącego zmniejszenia zużycia energii przez silniki trakcyjne o zapłonie iskrowym.

5. Opracowany system zasilania charakteryzuje się wieloma zaletami istotnymi przy dwupaliwowym zasilaniu silnika ZI. Do zalet tych należy zaliczyć:

- możliwość rozruchu silnika na samej benzynie, co pozwala zachować jego własności rozruchowe jak przy zasilaniu tradycyjnym;

- możliwość zasilania dwupaliwowego przy aktywnie zmienianym udziale alkoholu zależnie od obciążenia i prędkości obrotowej silnika;

- możliwość stosowania dużych udziałów alkoholu bez niebezpieczeństwa rozwarstwienia się paliw;

- możliwość podwyższenia stopnia sprężania i automatyczne przechodzenie na zasilanie samym alkoholem przy maksymalnych obciążeniach silnika.

Badania opisywane $w$ niniejszej pracy zostaty wykonane $w$ ramach grantu badawczego $\mathrm{nr}$ PB 45343/B/T02/2007/33 finansowanego przez Ministerstwo Nauki i Szkolnictwa Wyższego.

Paper reviewed/Artykut recenzowany

\section{Bibliography/Literatura}

[1] Merkisz J., Pielecha I.: Alternatywne napędy pojazdów. Wyd. Politechniki Poznańskiej, Poznań 2006.

[2] Baczewski K., Kołdoński T.: Paliwa do silników o zapłonie iskrowym. WKi乇, Warszawa 2005.

[3] Kowalewicz A.: Metanol jako paliwo do silników spalinowych. Silniki Spalinowe nr 3-4, 1992.

[4] Kotowski W., Klimiec J., Marcjasz-Siemiątkowska I.: Możliwości wykorzystania metanolu i jego pochodnych jako paliw silnikowych. Przemysł Chemiczny nr 80/1/2001.

[5] Lotko W.: Studium zastosowań paliw alternatywnych w silnikach o zapłonie samoczynnym. Wydawnictwo Politechniki Radomskiej, 1999.

[6] Jakubowski J.: Silniki samochodowe zasilane paliwami zastępczymi. WKit, 1987.

[7] Stelmasiak Z., Larisch J., Semikow J.: Preliminary tests on dual fuel spark ignition engine fuelled with methanol and gasoline, Combustion Engines No 3/2008 (134), pp. 24-33, 2008.

Mr. Zdzisław Stelmasiak, DSc, DEng. - Professor in the Faculty of Mechanical Engineering and Computer Sciences at Technical University of Bielsko-Biala. Dr hab, inż. Zdzistaw Stelmasiak - profesor na Wydziale Budowy Maszyn i Informatyki Akademii Techniczno-Humansitycznej w Bielsku-Białej. e-mail: zstelmasiak@ath.bielsko.pl

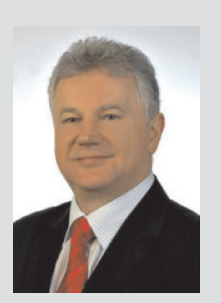

[8] Stelmasiak Z., Larisch J., Semikow J.: Analysis of a chosen combustion parameters of dual fuel SI engine fuelled with alcohol and gasiline Combustion Engines No 2/2009 (137), pp. 29-36, 2009.

[9] Stelmasiak Z., Larisch J., Semikow J.: Some aspects of bifuel SI engine run on alcolol and gasoline, 12th EAEC European Automotibe Congress Bratislava 2009.

[10] Brinkman N., Halsall R., Jorgensen, S.W., Kirwan J.E.: The Development of Improved Fuel Specifications for Methanol (M85) amd Ethanol (Ed85). SAE Technical Paper 940764.

[11] Kelly K.J., Bailey B.K., Coburn T.C., Clark W., Lissiuk P.: Federal Test Procedure Emissions Test Results from Ethanol Variable-Fuel Vehicle Chevrolet Luminas. SAE Technical Paper 961092.

[12] en.wikipedia.org/wiki/Alcohol_fuel\#Alcohol_in_Brazil, 2008.

[13] www.greencarcongress.com/2008/08/alcohol-boostin.html, 2008.

Mr. Janusz Semikow, DEng. - postgraduate in the Faculty of Mechanical Engineering and Computer Sciences at Technical University of Bielsko-Biala. Mgr inż. Janusz Semikow - doktorant na Wydziale Budowy Maszyn i Informatyki Akademii Techniczno-Humansitycznej w Bielsku-Bialej. e-mail: jsemikow@poczta.onet.pl

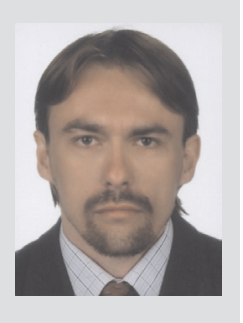

